\title{
PENGARUH OPERASIONAL KAPAL DAN PENGOPERASIAN GENERATOR TERHADAP BEBAN DAYA LISTRIK
}

\author{
Lutfi Adi Prabowo ${ }^{1}$, Abdi Seno ${ }^{2}$, Darul Prayogo*3 \\ ${ }^{1,2,3}$ Politeknik Ilmu Pelayaran Semarang (Teknika, Politeknik Ilmu Pelayaran Semarang, Indonesia) \\ ${ }^{1}$ lutfikiku@gmail.com \\ 2abdiseno710421@gmail.com \\ 3arul@pip-semarang.ac.id
}

\begin{abstract}
ABSTRAK
Beban Daya Listrik merupakan semua beban yang ditanggung pembangkit listrik. Tujuan penelitian ini untuk menganalisis pengaruh kondisi operasional kapal terhadap beban daya listrik di kapal, untuk menganalisis pengaruh operasi generator terhadap beban daya listrik di kapal dan untuk menganalisis pengaruh kondisi operasional kapal dan operasi generator terhadap beban daya listrik di kapal. Metode penelitian ini penulis menggunakan metode kuantitatif mengenai pengaruh kondisi operasional kapal dan operasi generator terhadap beban daya listrik. Dengan menggunakan sofeware program aplikasi SPSS sebagai alat untuk mengolah data. SPSS adalah teknik analisa data untuk menganalisa korelasi dan pengaruh antara variabel bebas dan variabel terikat. Sumber data yang akan dianalisis dari data kapal tentang beban daya listrik. Berdasarkan hasil penelitian yang telah dilakukan penulis di kapal adalah. (1) X1 berpengaruh (negative) terhadap Y, dengan koefisien determinan R squere X1 (kondisi operasional kapal) terhadap Y (beban daya listrik) ada sebesar 4,2 \% (2) X2 berpengaruh (positive) terhadap Y, dengan koefisien determinan R squere $\mathrm{X} 2$ (operasi generator) terhadap Y (beban daya listrik) ada sebesar 1,1\% (3) X1 dan X2 berpengaruh (positive) terhadap $\mathrm{Y}$, dengan koefisien determinan $\mathrm{R}$ squere $\mathrm{X} 1$ dan $\mathrm{X} 2$ terhadap $\mathrm{Y}$ ada sebesar 4,4\%.
\end{abstract}

Kata kunci: operasional, generator, beban listrik.

\begin{abstract}
[Title: Effect Of Ship Operation And Generator Operation On Electricity Load]. Abstract contains 2 Electrical Power Load is everything that beared and occurred by electrical power. The purpose of this research is to analyze the operational condition of vessel and generatior operation toward electrical power load on board. The research used quantitative method with application program to analyze the correlation and the impact between independent variable and dependent variable from the electrical power load data.The result of the rese arch done by the researcher on board is X1 (operational condition of vessel) took negative effect toward Y (electrical power load) for $4.2 \%$. X2 (generator operation) took positive impact toward Y (electrical power load) for $1,1 \%$. Together, it created positive impact for $4.4 \%$.
\end{abstract}

Keywords: operational, generator, electrical load

\section{PENDAHULUAN}

Operasional merupakan batas dan pedoman dalam melakukan suatu kegiatan. Kapal merupakan moda untuk mengangkut barang, penumpang, atau bulks seperti batubara untuk keperluan industri. Pengoperasian kapal adalah kegiatan kapal dalam berbagai kondisi saat kapal di laut. [1] Pengoperasian Generator merupakan interkoneksi antara beberapa generator dalam satu kesatuan, baik tunggal maupun bersama-sama untuk memikul beban. Generator tersebut akan diparalelkan untuk disinkronkan secara manual atau otomatis, guna mendapatkan daya yang lebih besar. [2]

Pengertian generator $\mathrm{AC}$ adalah mesin yang mengubah energi mekanik (kinetik) menjadi energi listrik dengan bantuan induksi magnet. Transformasi energi terjadi karena perubahan medium maget menjadi kumparan / anchor (tempat naiknya tegangan menuju generator). [2]

Beban listrik merupakan segala sesuatu yang membutuhkan tenaga listrik. Beban listrik adalah motor listrik, penerangan dan peralatan yang 
dihubungkan dengan sumbernya. Tenaga Listrik adalah akumulasi energi yang diserap atau dihasilkan suatu rangkaian. Sumber energi berupa tegangan listrik akan menghasilkan tenaga listrik, sedangkan beban yang terhubung akan terserap dengan tegangan tersebut. Tenaga listrik adalah tingkat konsumsi energi dalam rangkaian listrik. [3]

Pada saat kapal berlabuh, kondisi genset terisi penuh $200 \mathrm{~kW}$, oleh karena itu akan mengalami kelebihan beban dan kemungkinan menyebabkan pemadaman listrik. Pada kesempatan lain, 2 generator dibebani secara paralel dan penuh untuk masing-masing generator $160 \mathrm{~kW}$ untuk proses discharging dan menggunakan 4 crane agar cepat selesai. Ketiga generator tersebut akan dioperasikan bersamaan dengan beban masing-masing generator antara $160 \mathrm{~kW}$ hingga $240 \mathrm{~kW}$. Saat crane beroperasi, watt meter menunjukkan angka yang selalu bergerak. Untuk mengantisipasi apa pun, dibutuhkan kesadaran oleh para engineer, agar bagian dek menggunakan 3 crane. Penggunaan bahan bakar akan meningkat jika debit pemuatan tertunda dan waktu operasional generator diesel. Kondisi Pengoperasian Kapal dan Pengoperasian Generator terhadap Beban Tenaga Listrik di MV. DK-02 merupakan mata pelajaran yang akan dipelajari.

\section{METODE}

Metode penelitian adalah cara ilmiah untuk memperoleh data dengan tujuan dan kegunaan tertentu. Berdasarkan definisi tersebut terdapat 4 kata kunci yang perlu diperhatikan yaitu keilmuan, data, tujuan dan kegunaan.

Metode kuantitatif dengan analisis deskriptif untuk memperkuat temuan, analisis data dan deskriptif akan membantu untuk menguji hubungan antara variabel bebas yaitu kondisi operasional kapal dan pengoperasian generator terhadap variabel terkait yaitu beban daya listrik.

Analisis data merupakan proses mencari dan menyusun data secara sistematis dari wawancara, catatan lapangan, dan materi lainnya, sehingga akan lebih mudah dipahami dan pendirinya akan diinformasikan kepada orang lain.

\section{Analisa deskriptif}

Metode kuantitatif yang digunakan untuk menjelaskan masalahnya adalah SPSS.

\section{Uji Validitas}

Uji validitas digunakan untuk mengetahui kelayakan questios dalam mendefinisikan suatu variabel. Teknik uji validitas menggunakan korelasi Bivariat Pearson dan Koreksi Item-Total Korelasi.

\section{Uji F}

Uji $F$ digunakan untuk menguji kebenaran hipotesis alternatif; apakah model yang dipilih peneliti benar. Goodness of Fit adalah semua pengaruh variabel independen terhadap variabel dependen.

Ho: $p=0$ (hubungan lemah)

Hai: $p \neq 0$ (hubungan tidak lemah)

Jika nilai signifikan (p-value) $<0,05$ (signifikan 5\%) dan atau nilai $\mathrm{F}>\mathrm{F}$ tabel, maka Ho ditolak dan $\mathrm{Ha}$ diterima. Artinya, terdapat pengaruh yang sama antara variabel independen terhadap dependen.

4. Analisis Regresi Linear Berganda

Analisis Regresi Linier Berganda digunakan untuk memprediksi sesuatu, dimana dalam model terdapat variabel terikat dan variabel bebas. [8] Pengaruh variabel independen terhadap variabel dependen adalah regresi serupa.

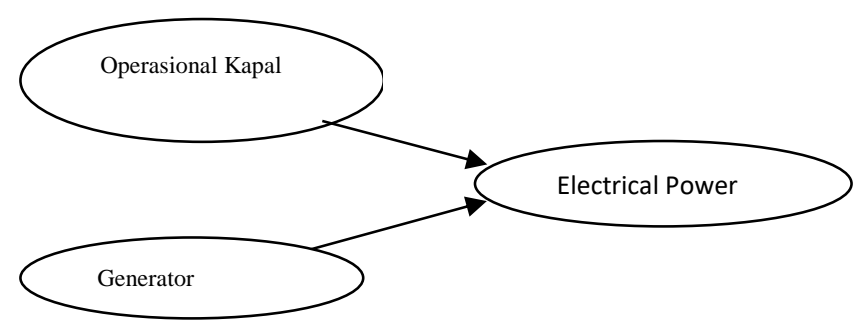

Gambar 1. Desain Penelitian

\section{HASIL DAN PEMBAHASAN}

Variabel deskriptif ini untuk menjelaskan data variabel "Y" yaitu beban daya listrik. Variabel X1 dan X2 merupakan data ordinal dari kondisi operasional. Mean, Median, Modus, Maximum dan Minimum Tabel 1. Mean, Median, Modus, Maximum dan Minimum

\begin{tabular}{c|c}
\hline Mean & 132,29 \\
Median & 140,00 \\
Mode & 140 \\
Minimum & 80 \\
Maximum & 180 \\
\hline
\end{tabular}


Penggunaan beban daya listrik pada MV. DK-02 diperoleh dengan hasil rata-rata $132,29 \mathrm{~kW}$. Sedangkan median dari total beban daya listrik yang sering digunakan adalah $140 \mathrm{~kW}$. Modus beban daya listrik di atas adalah $140 \mathrm{~kW}$.

Nilai maksimum yang didapat sebesar $180 \mathrm{~kW}$ merupakan penggunaan beban terbesar saat melakukan penelitian. Beban daya listrik minimum yang didapat adalah $80 \mathrm{~kW}$ yang penggunaannya hampir tidak terpakai pada saat generator dioperasikan.

b. Frekuensi

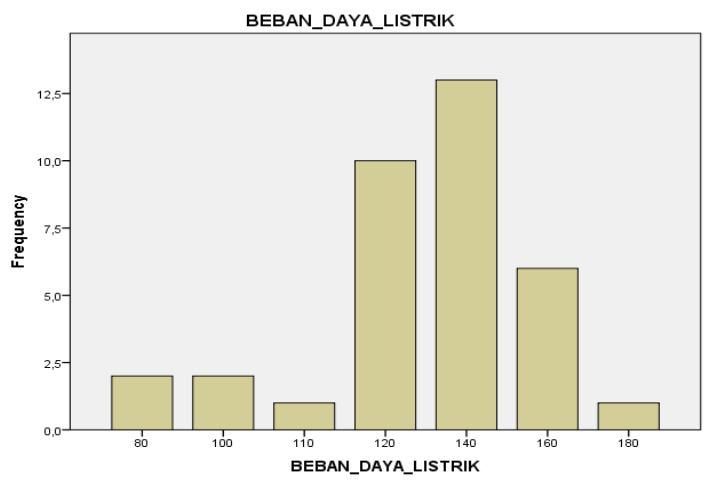

Gambar 1. Diagram Frekuensi

Penggunaan beban daya listrik seringkali ditunjukkan pada penggunaan beban daya listrik yaitu $140 \mathrm{~kW}$. Disusul $120 \mathrm{~kW}, 80 \mathrm{~kW}$, dan $100 \mathrm{~kW}$, digunakan biasanya beban $110 \mathrm{~kW}$ dan $180 \mathrm{~kW}$ dengan frekuensi.

\section{Korelasi Variabel X1 dengan $Y$}

Tabel 2. korelasi Variabel X1 dengan Y

\begin{tabular}{l|l|c|c}
\cline { 3 - 3 } \multicolumn{2}{c}{} & $\begin{array}{r}\text { KON_OPE_ } \\
\text { KAPAL }\end{array}$ & $\begin{array}{c}\text { BEBAN_DAY } \\
\text { A_LISTRIK }\end{array}$ \\
\hline $\begin{array}{l}\text { KON_OP } \\
\text { E_KAPA }\end{array}$ & $\begin{array}{l}\text { Pearson } \\
\text { Correlation }\end{array}$ & 1 &,- 205 \\
Sig. (2-tailed) & &, 238 \\
$\mathrm{~N}$ & 54 & 35 \\
BEBAN_ $_{\text {DAYA_L }}$ & $\begin{array}{l}\text { Pearson } \\
\text { Correlation }\end{array}$ &,- 205 & 1 \\
ISTRIK & Sig. (2-tailed) &, 238 & \\
\hline
\end{tabular}

Diperoleh Kondisi Operasional Kapal (X1) dengan Beban Daya Listrik (Y) pada plot pencar di sebelah kiri berarti "negatif". Hasil korelasi Pearson Sig = $0,238(23,8 \%)>5 \%$ artinya Ho diterima dan Hi ditolak.

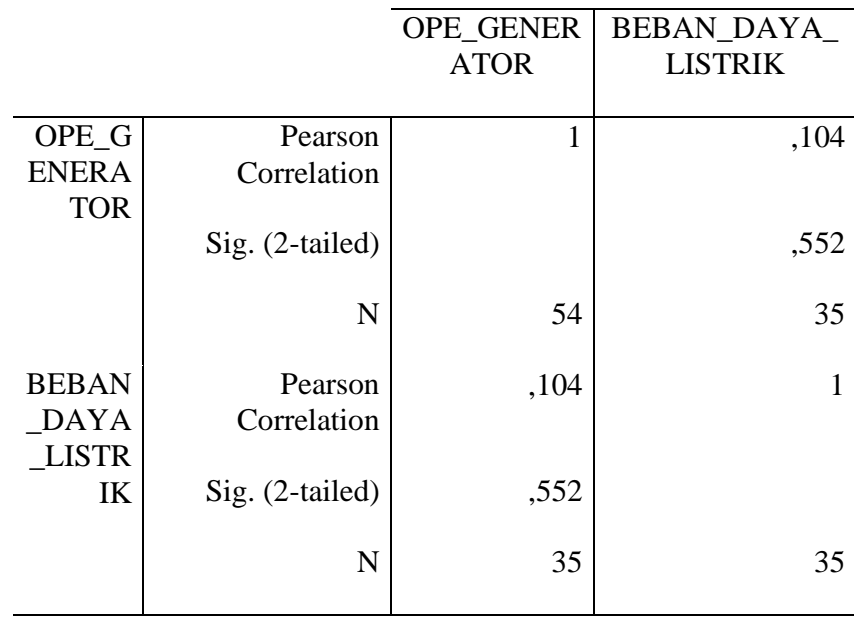

Ada hubungan antara Kondisi Operasi Kapal (X1) dengan Beban Tenaga Listrik (Y) yang membuatnya menjadi lemah. Untuk memperkuat pernyataan tersebut diperoleh nilai korelasi empiris $(\mathrm{p} 1)=-0.205$. Nilai tersebut menunjukkan korelasi antara $\mathrm{X} 1$ dan $\mathrm{Y}$ bertanda negative.

Pengoperasian Generator (X2) dengan Beban Daya Listrik (Y) dalam plot pencar di sisi kanan dengan nilai 'positif'. Hasil Korelasi Pearson Sig $=0,552(55,2 \%)$. Nilai $55,2 \%>5 \%$ artinya Ho diterima dan Hi ditolak. Hubungan antara X2 dan Y lemah. Untuk memperkuat pernyataan tersebut, diperoleh nilai korelasi empiris $(\mathrm{p} 2)=0,104$ yang menunjukkan korelasi antara X2 dan Y positif.

\section{Analisis regresi $\mathrm{X} 1$ dan $\mathrm{Y}$}

Tabel 4. regresi $\mathrm{X} 1$ and $\mathrm{Y}$

\begin{tabular}{|c|c|c|c|c|c|}
\hline \multirow[b]{2}{*}{ Model } & \multicolumn{2}{|c|}{$\begin{array}{l}\text { Unstandardized } \\
\text { Coefficients }\end{array}$} & \multirow{2}{*}{$\begin{array}{c}\begin{array}{c}\text { Standard } \\
\text { ized } \\
\text { Coeffici } \\
\text { ents }\end{array} \\
\text { Beta }\end{array}$} & \multirow[b]{2}{*}{$\mathrm{t}$} & \multirow[b]{2}{*}{ Sig. } \\
\hline & B & $\begin{array}{l}\text { Std. } \\
\text { Error }\end{array}$ & & & \\
\hline \begin{tabular}{l|l}
1 & (Constant)
\end{tabular} & 5,351 & 1,720 & & 3,111 & ,004 \\
\hline $\begin{array}{l}\text { BEBAN_D } \\
\text { AYA_LIS } \\
\text { TRIK }\end{array}$ &,- 015 & ,013 &,- 205 & $-1,201$ & ,238 \\
\hline
\end{tabular}

Koefisien Tidak Standar (B) diperoleh nilai $\alpha=5,351$ dan $\beta 1=-0,015$. Ekuitas terbentuk: $Y=5,351-0,015$ $\mathrm{X} 1$. Untuk menguji ekuitas di atas apakah menerima atau menolak hipotesis yang diajukan, terdapat distribusi 'F' terhadap tabel keluaran ANOVA. 


\section{Analisis regresi $\mathrm{X} 2$ dan $\mathrm{Y}$}

Tabel 5. regresi X2 dan $\mathrm{Y}$

\begin{tabular}{|c|c|c|c|c|c|c|}
\hline & \multirow{2}{*}{ Model } & \multicolumn{2}{|c|}{$\begin{array}{l}\text { Unstandardize } \\
\text { d Coefficients }\end{array}$} & \multirow[t]{2}{*}{$\begin{array}{c}\text { Standardi } \\
\text { zed } \\
\text { Coefficien } \\
\text { ts }\end{array}$} & \multirow{2}{*}{$\mathrm{T}$} & \multirow{2}{*}{ Sig. } \\
\hline & & B & $\begin{array}{l}\text { Std. } \\
\text { Error }\end{array}$ & & & \\
\hline \multirow[t]{2}{*}{1} & (Constant) & 1,739 & ,729 & & $\begin{array}{r}2,38 \\
5\end{array}$ & ,023 \\
\hline & $\begin{array}{l}\text { BEBAN_DA } \\
\text { YA_LISTRI } \\
\mathrm{K}\end{array}$ & ,003 & ,005 & , 104 & 601 & ,552 \\
\hline
\end{tabular}

Koefisien Tidak Standar (B) diperoleh $\alpha=1,739$ dan $\beta 2=0,003$. Ekuitas yang dibentuk adalah: $\mathrm{Y}=1,739+$ $0,003 \times 2$.

Untuk menguji ekuitas, apakah menerima atau menolak hipotesis yang diajukan, distribusi $\mathrm{F}$ ditentukan pada tabel output ANOVA.

\section{Regresi Linier Ganda}

$\mathrm{Y}=\mathrm{a}+\beta 1 \mathrm{X} 1+\beta 2 \mathrm{X} 2$

\section{X1}

B1

\section{$\mathbf{Y}$}

X2

B2

Gambar 2. Hipotesis X1 and X2 terhadap Y

Tabel 6. Koefisien X1, X2 and Y

\begin{tabular}{c|c|c|c|c|c}
\hline \multirow{2}{*}{ Model } & \multicolumn{2}{|c|}{$\begin{array}{c}\text { Unstandardized } \\
\text { Coefficients }\end{array}$} & $\begin{array}{c}\text { Standardi } \\
\text { zed } \\
\text { Coefficie } \\
\text { nts }\end{array}$ & T & \multirow{2}{*}{ Sig. } \\
\cline { 2 - 4 } & B & Std. Error & Beta & \\
\hline \multirow{2}{*}{$1 \begin{array}{c}\text { KON_OPE_ } \\
\text { VESSEL } \\
\begin{array}{c}\text { OPE_GENE } \\
\text { RATOR }\end{array}\end{array}$} & $-2,529$ & 2,383 &,- 190 & $-1,061$ &, 296 \\
\hline
\end{tabular}

Koefisien Tidak Standar (B) diperoleh nilai $\alpha=$ 136.989 dan $\beta 1=-2.529 ; \beta 2=1.694$. Persamaan yang terbentuk adalah: $\mathrm{Y}=136.989-2.529 \mathrm{X} 1+1.694 \mathrm{X} 2$.
Untuk menguji persamaan menerima atau menolak hipotesis yang disebutkan perhitungan distribusi ' $F$ ' dilakukan pada tabel keluaran ANOVA

Tabel 7. ANOVA X1, X2, and Y

\begin{tabular}{c|c|c|c|c|c|c}
\hline \multicolumn{2}{c|}{ Model } & $\begin{array}{c}\text { Sum of } \\
\text { Squares }\end{array}$ & Df & $\begin{array}{c}\text { Mean } \\
\text { Square }\end{array}$ & F & Sig. \\
\hline 1 & Regression & 765,947 & 2 & 382,973 &, 745 &, $483^{\mathrm{b}}$ \\
& Residual & 16451,196 & 32 & 514,100 & & \\
& Total & 17217,143 & 34 & & & \\
\hline
\end{tabular}

Nilai $\mathrm{F}=0,745$ dan $\mathrm{Sig}=0,483(48,3 \%)$. Nilai Sig 48,3\%> 5\% yang artinya Ho diterima dan Hi ditolak. Persamaan itu tidak linier atau X1, X2, tidak mempengaruhi $\mathrm{Y}$.

Untuk mengetahui seberapa besar X1, X2 berkontribusi pada $\mathrm{Y}$ kita dapat melihat Koefisien Determinasi (R Square) pada Model Ringkasan

Tabel 8. Model Summary X1, X2, dan Y

\begin{tabular}{l|r|r|r|r}
\hline Model & \multicolumn{1}{|c|}{$\mathrm{R}$} & R Square & $\begin{array}{c}\text { Adjusted R } \\
\text { Square }\end{array}$ & $\begin{array}{c}\text { Std. Error of the } \\
\text { Estimate }\end{array}$ \\
\hline 1 &, $211^{\mathrm{a}}$ &, 044 &,- 015 & 22,674 \\
\hline
\end{tabular}

Nilai $\mathrm{R} 2=0,044$ atau $4,4 \%$. Nilai tersebut menunjukkan bahwa variabel Kondisi Operasi Kapal (X1), Operasi Generator (X2) secara simultan memberikan kontribusi terhadap Hasil Beban Tenaga Listrik (Y) sebesar 4,4\%. Dengan hasil tersebut masih terdapat $95,6 \%$ data beban daya listrik (Y) yang dipengaruhi oleh variabel lain.

Variabel X1 merupakan data ordinal yang tidak bernilai dan merupakan gambaran dari setiap kondisi kondisi operasional kapal saat kondisi sandar untuk operasi kargo, manuver, saat melintas laut (sailing), jangkar untuk muat kargo. Variabel X2 merupakan data dari setiap operasi generator yang merupakan operasi tunggal (run 1), paralel (run 2), dan paralel (run 3). Pengeluaran tenaga listrik untuk mencari nilai ratarata, nilai tengah, dan nilai pengeluaran yang hampir sama memiliki hasil yang hampir sama dan sering dicatat pada biaya yang digunakan dari semua kondisi operasional kapal, dan semua kondisi pengoperasian pembangkit di setiap pengoperasian pembangkit listrik. Penggunaan biaya tenaga listrik memperoleh rata-rata 
(mean) 132,29 kW, nilai tengah (median) dari keseluruhan $140 \mathrm{~kW}$, nilai sering muncul (mode) 140 $\mathrm{kW}$, nilai maksimum $180 \mathrm{~kW}$ dan nilai minimum 80 kW biaya pemakaian genset . Frekuensi penggunaan beban daya listrik dengan penggunaan sering muncul $140 \mathrm{~kW}, 160 \mathrm{~kW}, 120 \mathrm{~kW}, 80 \mathrm{~kW}$ dan $100 \mathrm{~kW}$ beban biasanya ditemukan untuk $110 \mathrm{~kW}$ dan $180 \mathrm{~kW}$ dengan frekuensi 1 untuk masing-masing biaya.

\section{Korelasi antar variabel}

Nilai koefisien korelasi person sig X1 sebesar 0,238 kondisi operasional kapal berpengaruh terhadap beban daya listrik sebesar 23,8\%. Dengan demikian dapat disimpulkan bahwa kondisi operasional kapal terhadap beban tenaga listrik tergolong lemah (terpengaruh).

Nilai koefisien korelasi person sig X2 sebesar 0,552 pengoperasian generator berpengaruh terhadap beban daya listrik sebesar 55,2\%. Dengan demikian dapat disimpulkan bahwa pengoperasian genset berpengaruh terhadap beban daya listrik yang tidak lemah.

\section{Regresi antar variabel}

Nilai persamaan regresi adalah $\mathrm{Y}=5,351-0,015 \mathrm{X} 1$. Kemudian X1, nilai R Square adalah 0,042, kondisi operasional kapal (X1) mempengaruhi variabel yang berhubungan dengan biaya tenaga listrik (Y) sebesar $4,2 \%$ sedangkan sisanya $95,8 \%$ dipengaruhi oleh variabel lain.

Nilai persamaan regresi adalah $\mathrm{Y}=1,739+0,003 \mathrm{X} 2$. Kemudian $\mathrm{X} 2$, nilai $\mathrm{R}$ Square adalah 0,011, pengoperasian generator (X2) mempengaruhi variabel yang berhubungan dengan beban daya listrik (Y) sebesar $1,1 \%$ sedangkan sisanya 98,9\% dipengaruhi oleh variabel lain.

Nilai (X1 dan X2) R Square sebesar 0,044, variabel bebas kondisi operasional kapal (X1) dan variabel bebas pengoperasian genset (X2) dapat mempengaruhi variabel yang berkaitan dengan beban daya listrik (Y) sebesar 4,4\%, sedangkan variabel bebas lainnya 95,6\%. Dengan demikian kondisi operasional kapal dan pengoperasian generator terhadap beban tenaga listrik berdampak rendah. Dan sisanya 95,6\% mempengaruhi variabel bebas lainnya.

Dari perhitungan terkait adalah 95,6\%. Penggunaan beban tenaga listrik dapat dipengaruhi oleh variabel bebas seperti aliran listrik, beban generator, beban induktif. Beban lainnya adalah beban motor listrik, trafo, relai dan semua beban kumparan kawat yang dapat menyebabkan listrik tidak stabil. Motor listrik yang sudah lama digunakan dan menyebabkan biaya berubah tidak sesuai dengan plat nama pada pemakaian biaya, faktor daya atau aliran yang masuk ke motor listrik. Bisa juga disebabkan oleh hilangnya volt yang mengalir dari generator ke peralatan listrik yang aktif.

\section{KESIMPULAN}

Berdasarkan hasil analisis dan ringkasan dapat diambil kesimpulan sebagai berikut: 1. X1 (kondisi operasional kapal) berpengaruh (negatif) terhadap Y (beban tenaga listrik) persamaan regresi $\mathrm{Y}=5,351-0,015 \mathrm{X} 1$. Nilai R square adalah 4,2\%. 2. X2 (pengoperasian generator) berpengaruh (positif) terhadap Y (beban daya listrik) persamaan regresi $\mathrm{Y}=1.739+0.003 \mathrm{X} 2$. Nilai $\mathrm{R}$ square adalah $1,1 \% 3 . \mathrm{X} 1$ (kondisi operasional kapal) dan X2 (pengoperasian generator) berpengaruh (positif) terhadap Y (beban tenaga listrik) persamaan regresi $\mathrm{Y}=136.989-2.529 \mathrm{X} 1+1.694 \mathrm{X} 2$. Nilai $\mathrm{R}$ square adalah 4,4\%. Dan sisanya 95,6\% mempengaruhi variabel lain yang berhubungan dengan penggunaan beban daya listrik.

\section{DAFTAR PUSTAKA}

[1] Nimpuno, Hanjoyo Bono, 2014, Kamus Bahasa Indonesia Edisi Baru, Jakarta: Tim Pandom Media Nusantara, Pandom Media Nusantara.

[2] Kosow, L. Irving, 1991, Electric Machinery And Transformer, Germany.

[3] Malana M Yusuf, 2017, Artikel Teknologi Pengertian Beban Resistif, Induktif, Dan Kapasitif Pada Jaringan Listrik AC. http://artikelteknologi.com/pengrtian-beban-resistif-induktifdan-kapasitifpadajaringanlistrik-ac

[4] Sugiyono, 2016, Metode Penelitian Kuantitatif, Kualitatif dan $R \& D$, Bandung: PT Alfabeta.

[5] Sugiyono, 2015, Memahami Penelitian Kualitatif, Bandung: Alfabeta.

[6] Kamus besar bahasa Indonesia (KBBI), (http.web.id/implementasi), Diakses pada tanggal 16 Mei 2019.

[7] Sujarweni, V. Wiratna, 2014, Metode Penelitian Lengkap, Praktis Dan Mudah Dipahami, Yogyakarta: Pustaka Baru Press. 
[8] Santoso, Singgih, 2017, Menguasai Statistik Dengan SPSS 24, Jakarta: PT Elex Media Komputindo 